\title{
SCHÖPFLIN ALADÁR A VASÁRNAPI UJSÁGBAN
}

A kötet, a szemünk elött kibontakozó Schöpflin-reneszánsz fontos lépéseként, a modernség egyik legkiemelkedőbb kritikusának írásaiból nyújt válogatást. A szerkesztő, sajtó alá rendező Széchenyi Ágnes nem a Nyugat tekintélyes ítészét hozta közel az olvasóhoz, hanem a Vasárnapi Ujság nagy munkabírású recenzensére irányította a figyelmet. Ez az életmü egészéből kimetszett korpusz és a belőle körvonalazódó bírálói arculat csak a teljes sajtótörténeti kompetenciával rendelkező és egyúttal a kritikus pályáját monografikus igénnyel feldolgozó irodalomtörténész alapos bevezető tanulmányának köszönhetően válhatott az olvasó számára hitelesen és tanulságosan hozzáférhetővé.

A kötet arra a kérésre ad kimerítő választ, hogyan történt az irodalom forgalmazása, eljuttatása a szerzőtől az olvasóig, a kezdődő modernség korszakában. Aligha volt alkalmasabb, rátermettebb munkás e feladat elvégzésére, mint Schöpflin Aladár, az irodalom modernizálódásának tőzsdeügynöke, a legnemesebb értelmében véve a szót. Rövid, tömör, de hallatlanul biztos és precíz, s ugyanakkor végtelenül diplomatikusan megfogalmazott jelzéseket leadni a piacon megjelent irodalmi-szellemi árukínálatról, s nyomban kijelölni a piacra belépő kulturális termékek árfolyamát.

A tőzsdeügynök nem tévedhetetlen. Schöpflin hibája inkább az udvarias túlértékelés volt, mint valóságos tehetségek elhamarkodott kitessékelése a pályáról. De kivételes rugalmassággal és fürgeséggel tudta korrigálni tévedéseit. Schöpflin egyik szemével a Franklin Kiadó érdekeire figyelt, s a hetilapja szempontjait sem tévesztette soha szem elől. Tudta, hogy az irodalmi termék a mü megszületése után nyomban kereskedelmi forgalomba kerül, s hogy az üzem olajozottan müködjön, számos udvariassági gesztust kell tenni az establishment képviselöinek, akiknek legalább jóindulatú közömbössége nélkülözhetetlen az értéktermelö kevesek törekvéseinek érvényesítéséhez. De az értő olvasó tudtára adta, hogy érvényben van számára egy láthatatlan abszolút mérce, amely szerint a fontos pozícióval rendelkező személyek és instanciák a kíméletes bánásmód ellenére is, elkerülve a ledorongolás szégyenét, könnyünek találtattak.

Kiterjedt nemzetközi látókör birtokában írt. Jól értesült volt, és fürgén tájékozódott. Széles „szociológiai” horizonttal rendelkezett, s ennek folytán az irodalom több, eltérő funkciójával számolt. Pontosan felmérte, hogy az általa tárgyalt mủvek iránt van-e közönségérdeklődés, és hogy a közönség mely igényeit elégítik ki. Számon tartotta az irodalmi regisztereket, az igényes, minőségi olvasók szempontjait helyezve előtérbe. Ha valóságos közönségigény kielégítésére alkalmas müvekkel találkozott, hangja türelmessé vált, legyen szó akár Szabolcska Mi- 
hályról, Herczeg Ferencről, az időközben konzervatív irányba fordult Kiss Józsefröl, a modernség irodalmi ellenfeleiről.

Nem szolgálta ki a nemzetközi müveltséggel hivalkodó elitizmus sznob igényeit. Meg tudta különböztetni a talmi csillogást a valóságos értékektől, ami a századforduló Magyarországán, éppen a nyugatossággal tüntető közönségréteg nevelése szempontjából kulcsfontosságú volt. Tudta, hogy leküzdhetetlen igény van a társadalomban az irodalom könnyed, szórakoztató funkciója iránt, és ahelyett, hogy szélmalomharcot folytatott volna ellene, mindig jelezte, ha egy kevésbé értékes mủ alkalmasnak bizonyult a szélesebb, kevésbé müvelt rétegek szórakoztatására. Egyetlen határra figyelt, amelyen ha a vizsgált mü átlépett, akkor a kritikus nem ismert kíméletet: a dilettantizmus képviselöit ostorral űzte ki a művészet templomából.

Erős hajlama volt konzervatív módon gyanakvóan, fenntartásokkal fogadni a női írást. De a jelentős, kiemelkedő női szerzőkkel és művekkel szemben letette a fegyvert. Nem véletlenül vált Kaffka Margit mủvészetének egyik legnagyobb bámulójává a korban. Roppant érzékenységet árult el a gyermekeknek szóló minőségi irodalom iránt. Nemcsak Molnár Ferenc Pál utcai fiúkjára figyelt fel, hanem a mára elhalványult emlékezetủ Sebők Zsigmond munkásságát is melegen méltatta, akinek a Dörmögő Dömötöre elevenebben fennmaradt, mint szerzői neve.

A Nyugat-mozgalom szelleméhez hüen, az irodalom, a formaadás elkötelezettje volt, a müvekben megfogalmazott valós vagy vélt igazságok sulykolásával szemben: a müvészet autonómiájának elvét engedmények nélkül a magáévá tette. A paraszti szegénység, a proletariátus nyomora, a nők felszabadítása és más fontos ügyek mellé csak akkor állt teljes meggyőződéssel, ha ezek a törekvések megfelelö mủvészi színvonalon körvonalazódtak. A társadalmi egyenlőtlenségek, igazságtalanságok, anomáliák iránt nem volt érzéketlen, de ezeket megengedő módon, tudomásul vevő attitüddel kezelte, elvárva, hogy az alsó rétegek szószólói a tiszta müvészet hangján szólaltassák meg a tömegek követeléseit.

Meg tudta becsülni az elődök eredményeit, a konfliktusok elsimításában, az ellentétek kiegyenlítésében volt érdekelt, s alkatilag sem volt a konfrontáció embere, de egy olyan korban kellett helytállnia, amelyben a modernség és a hagyományőrzés eröi egyre türelmetlenebbül, egyre fokozódó eltökéltséggel feszültek szembe egymással. Nem kerülhette el az állásfoglalást, nem csitíthatta el a harcba bocsátkozó táborok fegyvercsattogtatását. Felismerte, hogy mit vár el tőle az a hatalmas mozgalom, amelyet összefoglaló néven modernségnek nevezhetünk. Világosan és egyértelmüen a korszerüség, a nyitottság, a változtatni akarás oldalára állt.

Széchenyi Ágnes végtelenül tapintatosan bánik az általa közreadott hatalmas korpusz szerzőjével, de ez nem akadályozza meg őt abban, hogy időben és szellemi térben a helyére tegye hősét. Úgy közölte például Schöpflin méltatását Pintér Jenő magyar irodalomtörténetéröl, hogy kisebb formátumú betükkel hozzáfüzte Szabó Dezsőnek a Nyugat 1913-as évfolyamában írott fullánkos kritikáját. El kell 
ismernünk, hogy Schöpflin túlzott udvariassággal, indokolatlan elismeréssel fogadta ezeket a szintéziseket, s az elevenbe vágó túlzásoktól hemzsegő, barokkosan modoros Szabó Dezső kritika sokkal közelebb jár az igazsághoz. Széchenyi Ágnes hangtalan hozzátétele voltaképpen olyan szembesítés, amelyböl könyvének föhőse nem kerül ki győztesen.

Az ilyen kiegészítések elég gyakoriak a kötetben. A konfrontáció azonban nem leleplező szándékú. Sokkal gyakoribb, hogy két különböző szerzőtől származó méltatás egybehangzó, vagy esetleg vagylagosan arra hívja föl a figyelmet, hogy egy adott müvet különböző nézőpontokból lehet megítélni. Az is előfordul, hogy Schöpflin Vasárnapi Ujság-beli recenzióját Széchenyi Ágnes a kritikusnak más orgánumban ugyanarról a müröl közölt másik írásával párosítja. Ez utóbbi megoldás arra figyelmeztet, hogy a hetilapban Schöpflin egy meghatározott szerepkört tölt be, és ez egészen más mozgásteret biztosít számára, mint amikor például ugyanő a Nyugat tekintélyes kritikusaként nyilatkozik egy adott müröl.

Schöflin Gyulai Pál egy kritikai kötetéröl szólva megemlíti a kritikatörténészeknek azt a régi, de mindmáig élö önmegnyugtató érvét, amely szerint: ,a kritika önálló életü müfaj, nincs kötve ahhoz a könyvhöz, amelyröl íratott, sem ahhoz az időponthoz, amelyben keletkezett. Azoknak a könyveknek legnagyobb része, amelyeket Gyulai kritikájára méltatott, teljesen feledésbe merült már, a legkevésbé sem érdekel már minket, és mégis érdeklődéssel olvassuk a kritikákat Gyulaiért, aki írta őket”. Széchenyi Ágnes meggyőzött arról, hogy nincs így. Igen nagy munkával visszakereste, ki is volt az az Antal Gézáné, Jászay-Horváth Elemér, Meller Simon, Vértessy Gyula, és még sokan mások, a megbírált vagy méltatott könyvek szerzői. Apró betüs lapalji jegyzeteit sokszor nagyobb érdeklődéssel olvastam, mint a róluk szóló Schöpflin-kritikát. Félbeszakadt életpályák, alkalmi szerzőség, sikertelen kísérletek, beváltatlan nagy ígéretek, előkelő származású dilettánsok, a 19. század második felének magyar irodalmi televénye, amelyből a nagy tehetségek kivirítottak. Milyen tapló szívű olvasó az olyan, amelyiket a megbírált szerző kiléte, aspirációi, életstratégiái nem érdekelnek, hanem csak az, hogy egy adott munkájukról egy tekintélyes kritikus milyen megállapításokat tesz?

Az ilyen, olykor szembeötlő, olykor észrevétlen szerkesztői közbelépéseknek köszönhető, hogy ez az elriasztó vastagságú és látszólag csak egy szük szakmai közönség számára érdekes könyv valójában ínyenceknek való csemege.

(Schöpflin Aladár a Vasárnapi Ujságban 1898-1921. Feldolgozta és közreadja Széchenyi Ágnes. Budapest: Argumentum, 2018, 1178 o.)

Tverdota György

irodalomtörténész 